\title{
Soil resource supply influences faunal size-specific distributions in natural food webs
}

\author{
Christian Mulder • Henri A. Den Hollander • J. Arie Vonk • Axel G. Rossberg • \\ Gerard A. J. M. Jagers op Akkerhuis • Gregor W. Yeates
}

Received: 6 February 2009 /Revised: 6 April 2009 /Accepted: 6 April 2009 /Published online: 14 May 2009

(C) The Author(s) 2009. This article is published with open access at Springerlink.com

\begin{abstract}
The large range of body-mass values of soil organisms provides a tool to assess the ecological organization of soil communities. The goal of this paper is to identify graphical and quantitative indicators of soil community composition and ecosystem functioning, and to illustrate their application to real soil food webs. The relationships between log-transformed mass and abundance of soil organisms in 20 Dutch meadows and heathlands were investigated. Using principles of allometry, maximal use can be made of ecological theory to build and explain food webs. The aggregate contribution of small invertebrates such as nematodes to the entire community is high under low soil
\end{abstract}

Electronic supplementary material The online version of this article (doi:10.1007/s00114-009-0539-4) contains supplementary material, which is available to all users.

C. Mulder $(\bowtie) \cdot H$. A. Den Hollander

Department of Ecology, National Institute for

Public Health and the Environment,

Box 1, Bilthoven 3720 BA, The Netherlands

e-mail: Christian.Mulder@rivm.nl

\section{J. A. Vonk}

Department of Environmental Science,

Radboud University Nijmegen,

Box 9010, Nijmegen 6500 GL, The Netherlands

\author{
A. G. Rossberg \\ School of Biological Sciences, Queen's University Belfast, \\ Belfast BT9 7BL, UK \\ G. A. J. M. Jagers op Akkerhuis \\ Functional Biodiversity, ALTERRA, \\ Box 47, Wageningen 6700 AA, The Netherlands \\ G. W. Yeates \\ Landcare Research, \\ Private Bag 11052, \\ Palmerston North 4442, New Zealand
}

phosphorus content and causes shifts in the mass-abundance relationships and in the trophic structures. We show for the first time that the average of the trophic link lengths is a reliable predictor for assessing soil fertility responses. Ordered trophic link pairs suggest a self-organizing structure of food webs according to resource availability and can predict environmental shifts in ecologically meaningful ways.

Keywords Allometry - Ecological stoichiometry · Cascading trophic interactions - Carbon · Phosphorus . Nutrient cycling $\cdot$ Food webs $\cdot$ Food quality .

Soil invertebrates $\cdot$ Trophic link lengths

\section{Introduction}

Soil invertebrates have been thoroughly investigated during the last two decades. Although a huge collection of natural food webs from different terrestrial ecosystems was available for meta-analysis, Hunt et al. (1987) were able to realize the first quantitative description of the nutrient and energy fluxes in their soil community food web. They weighted trophic links and nodes (compartments) according to the carbon and nitrogen flow and the functional biomass of soil organisms. Hunt's model has been widely applied and improved, especially in the Netherlands (as extensively reviewed by Powell 2007). During the same time period, soil enrichment and structure indicators evolved, as well, to a large part due to progress in phylogenetic analyses. For instance, nematode feeding traits based on buccal morphology were confirmed by a recent barcoding of the terrestrial nematofauna (e.g., Holterman et al. 2006, 2008). Faunal traits, ranging from a simple continuous ranking according to the estimated life strategy of invertebrates to the trophic-based pathways as defined by Moore and Hunt (1988), Moore et al. (1988), and 
Yeates et al. (1993), can be used to assess disturbance effects on fauna and soil decomposition (e.g., Setälä et al. 1991; Yeates and Bongers 1999; Yeates 1999, 2003).

The energy efficiency of soil invertebrates influences the entire decomposition process (Curry 1986) and is likely to couple decomposition to food-web structure through feedbacks between food-web structure and community functioning. According to Kondoh (2005), for example, adapting foraging strategies enhances population responses by positive feedbacks between food-web complexity and species persistence. Further, Kondoh pointed out that trophic links may exist only for specific periods during population cycles. Many soil invertebrates, in general, and some evolving soil microbivores such as the resting stages of nematodes, adapt their position according to their life-history stage. The idea that one single prey can provide different resources is well known (Pimm and Rice 1987; Yeates 1987a; Setälä et al. 1996; Mikola and Setälä 1999; Loladze et al. 2004; Berlow et al. 2008). Brown (1988) suggested that under high energy availability, the specialization benefit outweighs the advantages of generalism, supporting, hence, populations of rare specialists, top predators and, indirectly, parasites of common species (cf. Pimm and Lawton 1978).

As a highly simplifying abstraction from binomial taxonomy, phylogenetic diversity, and life-history omnivory, allometric relationships typically relate to the slopes of linear relationships between the logarithmic body mass $\log (M)$ and other quantities such as the logarithmic numerical abundance $\log (N)$ or the logarithmic biomass $\log (B)$. Several scaling relationships have been postulated for ecosystems, among others for the minimum size of a given population at a given time, for a population's energyuse and for body-size distributions (e.g., Woodward et al. 2005; Brose et al. 2006; White et al. 2007; Hendriks and Mulder 2008). Relations between size and abundance have been widely explored for different biota (e.g., Woodward et al. 2005; Mulder et al. 2005a, 2008; Reuman et al. 2008). Allometry defines emergent characteristics of large data sets and provides one common currency to characterize food webs and their mass balance by comparing compartments of differently sized organisms.

Population biomass of soil invertebrates can be seen as dictated by how the occurrence of a given species changes under specific environmental conditions (e.g., Curry 1986; Yeates 1987b, c; Wardle 2002; Mulder et al. 2006, 2008), possibly reflecting underground resource exploitation and soil nutrient cycling (phosphorus depletion, carbon accumulation, etc.). As summarized by Cebrian et al. (2009), ecosystems with higher resource quality can, in fact, support much larger consumer biomass, higher consumption rates, and higher consumer-resource ratios than ecosystems with lower resource quality. Although trophically equivalent faunal groups can have dissimilar influences on nutrient uptake, it became clear that soil faunal groups that have different body-size averages differ in their effects on nutrient mineralization (Wardle 2002: his figure 2.9; Mulder 2006).

No species in the soil is isolated; all are part of a network interconnecting microbial and higher subunits. Let trophic links depict possible consumer-resource relationships, including microbial connections. A plausible characterization of the entire structure of a soil community food web could be given by the relative differences across trophic levels in the body size of the organisms therein. In this view, trophic links are tools to assess relative differences in body size and population density. Trophic links have been variously defined, but essentially, they concern prey-predator or resourceconsumer relationships. In some soil systems, the distance between the averages of small and large invertebrate populations is less than four orders of magnitude (Mulder et al. 2005a, 2006). These "Cartesian distances" can be averaged as length (see next section: "Materials and methods"), but this metric should not be confused with the number of trophic levels in a food chain (sensu Pimm and Kitching 1987). While most species' properties affect individual fitness and govern responses to their abiotic environment, the average length of trophic links can be regarded as a structural community response.

We propose that the distribution of the body-mass averages and the resource-consumer relationships (here, trophic links) reflect the dominating pathway of resource exploitation by soil organisms. To explain observed differences in allometric properties and food-web structure, we hypothesize that the increasing availability of soil resources favors larger and mobile invertebrates such as collembolans, mites, and enchytraeids (mesofauna) in contrast to smaller invertebrates such as nematodes (microfauna). If so, at least two intriguing questions arise: (a) Trait-based research spans an enormous array of ecological disciplines. Can the body-size distribution of soil organisms and the number and diversity of trophic links be used as integrating proxies to assess ecosystem functioning? (b) Wardle et al. (2004) coupled a relative fungal dominance in the soils to nutrient-poor litter. Can the averages of the trophic link lengths integrate the biological constraints which occur along a gradient in the fungal-tobacterial biomass ratio? Or, more generally, can the common responses of soil invertebrates to basic elemental resources (nutritional quality) be described by relative changes between the mesofauna and the microfauna or by allometric distributions of body-size values?

\section{Materials and methods}

Sites Twenty field sites in different biogeographic areas of the Netherlands were chosen for this study (Fig. 1); 

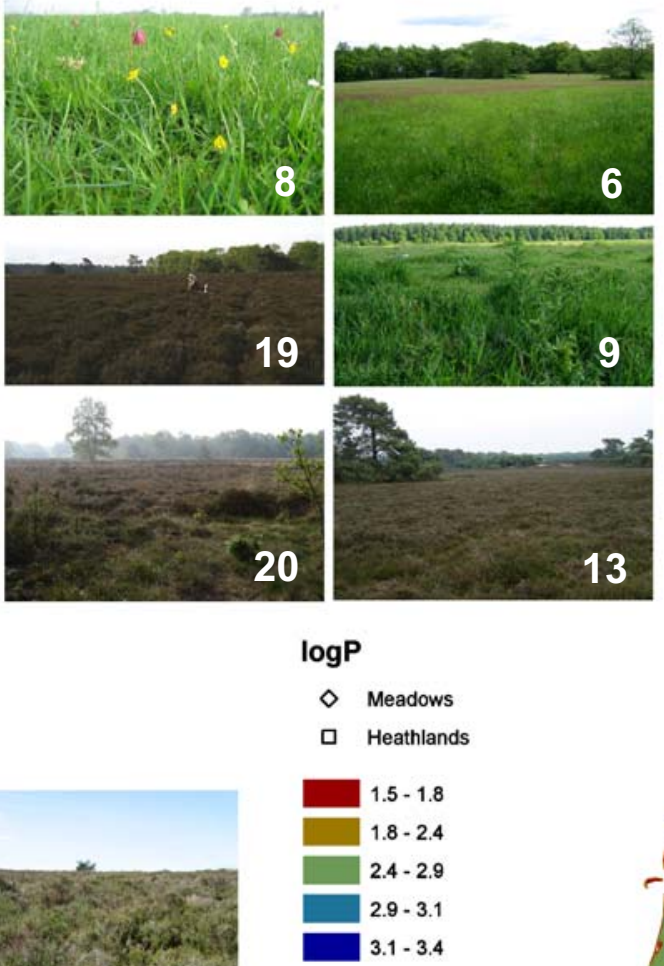

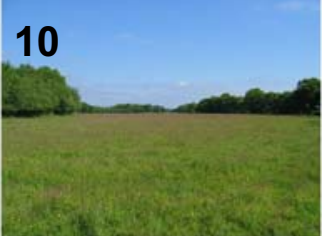

15

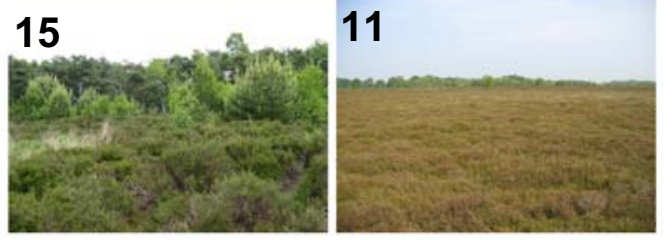

13
4

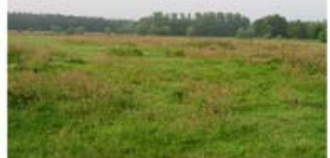

11
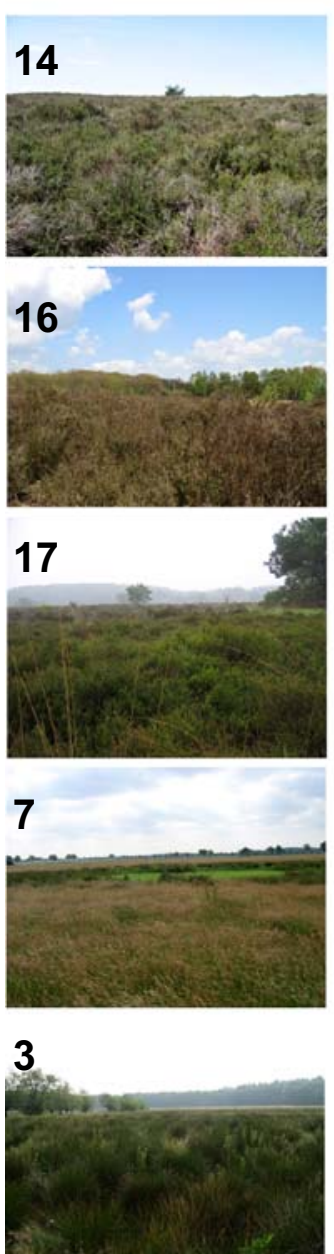

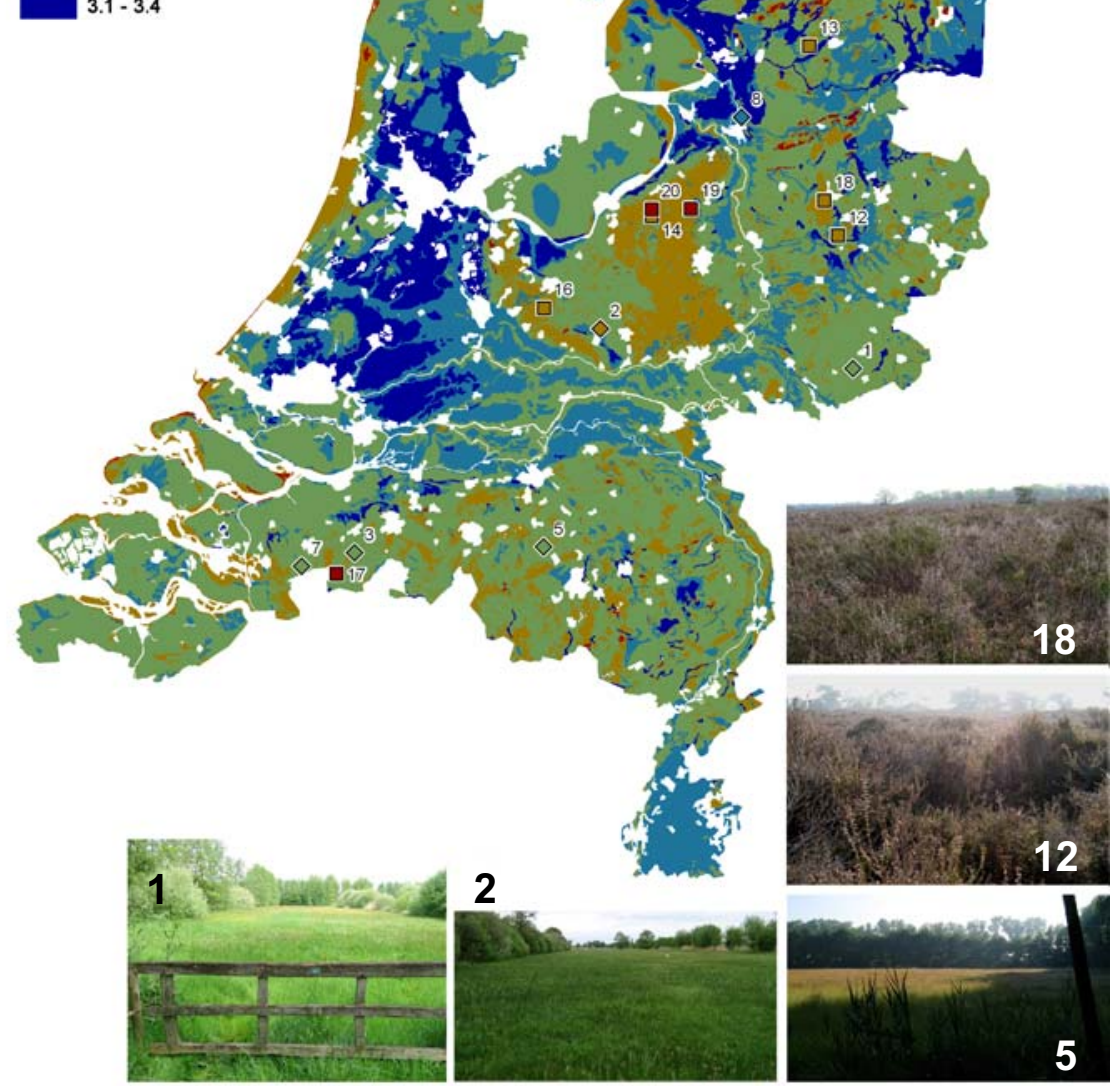

Fig. 1 Soil geographical database of the Netherlands: Phosphorus content. Aboveground vegetation is an important source for replenishment of phosphorus in the litter and the topsoil. Information was derived from a national data set according to CORINE Land Cover Classification. One picture of each investigated site during the field sampling is provided 
both abandoned meadows and heathlands were mostly undisturbed for some decades. All these investigated locations are managed by Provincial Landscapes (in Dutch: Provinciale Landschappen) and Forestry (in Dutch: Staatsbosbeheer). The ten meadows are selected from the National Monitoring Network for Flora, Environmental and Nature Quality. There are different kinds of meadows (1-10 of Fig. 1). The locations belong to either "wet, moderately nutrient-rich grassland" or to "grassland with herbs in sandy and peat areas." Holcus lanatus is one of the most prevalent grasses across the country, and Lolium perenne was characteristic of all the ten sampled locations. Orchids were found in moist, nutrient-poor, and weakly acidic environments. There are also different kinds of heathlands. Dry heathlands in the Netherlands are a cultural landscape, resulting from long-term burning, felling, and grazing. Apart from heather (Calluna vulgaris), a limited number of other species occur (11-20 of Fig. 1), such as Deschampsia flexuosa, Molinia caerulea, and Juniperus communis. Wet heathlands are characterized by Erica tetralix, Gentiana pneumonanthe, Narthecium ossifragum, and sedges.

Soils Monitoring activities were performed as part of the Dutch Soil Quality Network, a national framework designed in 1998 and used henceforth. The aim of this network is to obtain policy information regarding soil status and trends. It covers a site selection representative for over $80 \%$ of the Netherlands. A complete field sampling "round" takes five successive years (Mulder et al. 2003). Every year, at least 40 locations are sampled. In the current study, only Pleistocene sandy soils were taken into account. Soil cores were collected during the spring of 2004 using a randomized block design. On each location, 320 cores $(\varnothing$ $2.3 \mathrm{~cm})$ and ten cores $(\varnothing 5.8 \mathrm{~cm})$ were collected for microfauna and for mesofauna, respectively (Mulder et al. 2003, 2005a). One composite sample was obtained by mixing the 320 soil cores in a plastic container, and approximately $500 \mathrm{~g}$ were collected in glass jars for chemical, microbial, and nematological analyses. All these soils were analyzed in triplicate; carbon (total-C) was measured by loss of ignition (first hour at $550^{\circ} \mathrm{C}$ (LOI1) for organic $\mathrm{C}$, and another hour at $900^{\circ} \mathrm{C}$ (LOI2) for the inorganic C) on one soil sample, oven-dried at $105^{\circ} \mathrm{C}$; phosphorus (total-P) was determined by ashing samples on filters at $550^{\circ} \mathrm{C}$ followed by extraction with $\mathrm{HCl}$. The $\mathrm{HCl}$ extract was then measured according to Murphy and Riley (1962). Soil acidity was measured in $\mathrm{KCl}\left(\mathrm{pH}_{(\mathrm{KCl})}-\right.$ NEN5750). Nitrogen (total-N) was determined by the titrimetric method after distillation using a Büchi 321 apparatus (Kjeldahl destruction). During sampling, we took into account the recent local weather conditions. All sampling events occurred within 57 days, with an air temperature increase of less than $5^{\circ} \mathrm{C}$. The coefficient of variation of temperature was $23 \%$ in ${ }^{\circ} \mathrm{C}$.

Microbes Size and number of bacterial cells were investigated by fluorescent staining by (5-(4, 6-dichlorotriazin-2-yl) aminofluorescein (DTAF)) and a combination of microscopy and automatic image analysis. For the conversion of bacterial cell volume $\left(\mu \mathrm{m}^{3}\right)$ to dry biomass $(\mu \mathrm{g})$, we used the biovolume-to-carbon factor of Van Veen and Paul (1979), assuming a bacterial-carbon content of 50\% (Herbert 1976). Fungal measurements used a combination of direct microscopy and palynological treatments (Mulder and Janssen 1999). Stained hyphae were viewed with a Leitz epifluorescence microscope at 2,500×, and the lengths of the branches were estimated by the line intercept method. The mycelium volume $V\left(\mu \mathrm{m}^{3}\right)$ was estimated from $V=\pi\left(\frac{w}{2}\right)^{2} \times b$, where $w$ is the average hyphal width ( $\left.\mu \mathrm{m}\right)$ and $b$ the average hyphal branch-length $(\mu \mathrm{m})$. For the conversion of mycelium volume to biomass, we assumed a mean hyphal width of $2.5 \mu \mathrm{m}$ and the biovolume-to-carbon factor of Bakken and Olsen (1983).

Invertebrates Soil nematodes were extracted using funnel elutriation, sieving, and cottonwool extraction (Mulder et al. 2003, 2005b). All individuals within two clean 10-mL water suspensions were screened and counted with a stereomicroscope at low resolution. In two mounts in $4 \%$ formaldehyde, at least 150 individuals were identified at genus level by light microscopy, measured at a magnification of 400-600×, and subsequently assigned to feeding habits (Yeates et al. 1993). The body size of nematodes (in our samples ranging from about $200 \mu \mathrm{m}$ up to $1 \mathrm{~mm}$ length) and the body mass (differing almost three orders of magnitude) are closely correlated (Mulder et al. 2005a, b), making the conversion from individual length to dry weight easy and robust. Within the aforementioned block design, four $\varnothing 5.8 \mathrm{~cm}$ cores were selected for the microarthropods and kept separate until behavioral extraction by Tullgren funnels (Mulder et al. 2005b, 2006). The animals were sampled, observed at a magnification of 200-1,000× with a light microscope and subsequently assigned to feeding guilds on the basis of available literature including measurements of their carbohydrase activity. Since enzyme activity depends on the food components consumed prior to sampling, carbohydrases reflect the feeding guilds of microarthropods (Siepel 1994; Ponge 2000). Three carbohydrases have been measured: cellulase, chitinase, and trehalase. In the case of larger-sized adult microarthropods, such as Isotoma, Isotomurus, and Sminthurus, one specimen was enough for carbohydrases, but in virtually all instances, two to 20 adult individuals per taxon were necessary. The cellulase/trehalase activity was measured by quantifying the amount of added cellulose/trehalose which 
was transformed to glucose. (Glucose was assessed colorimetrically by the oxidation of the ortho-dianisidinedihydrochloride.) The chitinase activity was inferred from the turnover of $p$-nitrophenole- $N$ - $N$-diacetylchitobiose to $p$-nitrophenole, as measured at $450 \mathrm{~nm}$ by spectrophotometry. Enchytraeids were sampled in the remaining six $\varnothing 5.8 \mathrm{~cm}$-cores, extracted, weighted, and identified. Each individual worm was sampled manually and measured.

Allometry All animals were divided in body-size classes to estimate the corresponding faunal distribution. Besides enchytraeids and nematodes, whose empirical dry-weight averages were calculated for all individuals, including juveniles and resting stages, the $M$ averages for microarthropods were derived from the observed lengths and widths of sampled adults. Mass-abundance relationships, and body-size spectra, are typically described as the slopes of linear relationships between average body mass and numerical abundance, and between binned mass values and biomass, respectively. The mass-abundance slope is the coefficient $\alpha$ in the linear model $\log (N)=\alpha \log (M)+$ $\beta+\varepsilon$, fitted to data from a community food web. The same faunal data can be binned into body-mass classes, where the $\log (B)$ was computed in each bin as $\log (N)+\log (M)$, and regressed against $\log (M)$ in the center of each bin to get the biomass slope. We combined thus the dry body-mass averages of all the occurring individuals whose mean size fell within an equal interval of body size and plotted, separately for each site, the log summed biomass of all faunal taxa within $\log (M)$ bins against bin centers. In this way, the slopes of the linear regression of $\log$ summed biomass become a function of the bin centers on a $\log (M)$ scale (Mulder and Elser 2009). Because the biomass $B$ (here, $\mu \mathrm{g}$ ) of a taxon is its abundance $N$ (individuals $\mathrm{m}^{-2}$ ) times its (dry) body-mass $M(\mu \mathrm{g})$, the biomass slope indicates how $B$ changes with increasing $M$ bins. Although changes in the body size of bacterial cells are small (cell's size average varies only $\pm 11 \% \mathrm{SD}$ ), bacterial biomasses vary strongly due to the huge variation in the numerical abundance of cells (coefficient of variation 90.5\%). In contrast, fungal hyphae were regarded here as one unity (the mycelium), but with varying size. Fungal biomass changes less than bacterial biomass (coefficient of variation $48.5 \%$ ). In a way comparable to that of Reuman et al. (2009), we placed all taxa in a Cartesian plane with ordinate $\log (N)$ and abscissa $\log (M)$. In the present investigation, we sought explicitly to test for relationships between frequency and distribution of all the trophic links computable for the bacteria, fungi, and soil invertebrates. Then, the length of any trophic link (Reuman and Cohen 2004; Mulder et al. 2008) from the (microbial) resource $(r)$ to a consumer $(c)$ can be defined as $l=$ $\left|\log \left(M_{\mathrm{c}}\right)-\log \left(M_{\mathrm{r}}\right)\right|+\left|\log \left(N_{\mathrm{c}}\right)-\log \left(N_{\mathrm{r}}\right)\right|=\left|\log \left(M_{\mathrm{c}} / M_{\mathrm{r}}\right)\right|+$ $\left|\log \left(N_{\mathrm{c}} / N_{\mathrm{r}}\right)\right|$.
The (adimensional) length of any link is always positive, being zero only in the case of cannibalism. Moreover, for all possible trophic links, the occurrence of the preypredator ratios between the relative numerical abundances and between the body-mass averages has been investigated as well (Suppl. Mat. ESM 1). Computations used SAS version 9.1.3 Service Pack 3, PC-ORD version 4.20 and the EXCEL Visual Basic optimization toolbox. We worked based on a $5 \%$ significance level to evaluate statistics throughout the study.

\section{Results}

Soil stoichiometry influences faunal allometry

Soil concentrations of phosphorus and fungal biomass were negatively correlated (Pearson's correlation coefficient $\mathrm{Pr}=$ 0.0008 ), in contrast to the positive correlation between phosphorus and bacterial biomass $(\operatorname{Pr}=0.0278)$. We found evident patterns in the distribution of trophic links and fungal-to-bacterial biomass ratio versus soil $\mathrm{pH}$ and soil phosphorus-to-carbon ratio (Table 1). In Fig. 2, we explored how these environmental and biotic correlates mirror each other between ecosystem types. This pattern is very clear and strongly supports the view of resourceconsumer relationships as a function of biogeochemistry. As expected, bacteria exhibit positive responses to decreasing soil acidity, whereas fungi exhibit the opposite trends (Mulder et al. 2005b): the fungal-to-bacterial biomass ratio decreased with $\mathrm{pH}$ and phosphorus content.

Our allometric properties represent soil invertebrates, namely, free-living nematodes, mites, collembolans, and enchytraeids (Fig. 3). All three allometric proxies, namely, the slope of the regression line of $\log (N)$ on $\log (M)$, the biomass slope on the size spectra $(\log (B)$ on $\log (M)$-bins $)$, and the ratio between mesofauna (average $M>1 \mu \mathrm{g}$ dry weight) and microfauna $(M<1 \mu \mathrm{g}$ dry weight), were strongly correlated with soil nutritional quality (Fig. 3). All linear regression coefficients had $p$ values lower than 0.01 . We tested the independence of the environmental and biotic correlates. Soil $\mathrm{pH}$ was tested individually and compared with (a)biotic correlates (Pearson's coefficient $\operatorname{Pr}<0.0001$ in the case of phosphorus availability, direct correlation, and $\operatorname{Pr}<0.0001$ in the case of fungal-to-bacterial biomass ratio, inverse correlation) and removed from our other regression models. The correlation between the soil elemental resources (phosphorus-to-carbon ratio) and allometry $(\operatorname{Pr} \leq$ $0.0007)$ is slightly stronger than the correlation between the soil microbial resources (fungal-to-bacterial biomass ratio) and allometry $(\operatorname{Pr} \leq 0.0011)$.

Overall biomass slopes exhibited the mean of $0.0163 \pm$ $0.273 \mathrm{SD}$, indistinguishable from zero, as expected from 
Table 1 Abiotics and ecological interactions at the first trophic level

\begin{tabular}{|c|c|c|c|c|c|c|c|}
\hline Ecosystem & $\begin{array}{l}\text { Site } \\
\text { ID }\end{array}$ & $\begin{array}{l}\mathrm{C}: \mathrm{N}: \mathrm{P} \\
\text { (in mass units) }\end{array}$ & $\begin{array}{l}\text { Fungi } \\
\left(\mathrm{mg} \mathrm{m}^{-2}\right)\end{array}$ & 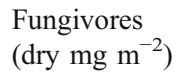 & $\begin{array}{l}\text { Bacteria } \\
\left(\mathrm{mg} \mathrm{m}^{-2}\right)\end{array}$ & 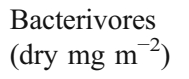 & $\begin{array}{l}F: B \text { ratio } \\
\text { Adimensional }\end{array}$ \\
\hline \multirow[t]{10}{*}{ Meadows } & 1 & $62: 6: 1$ & 173 & 446 & 2377 & 611 & 0.07 \\
\hline & 2 & $237: 10: 1$ & 228 & 740 & 1,794 & 156 & 0.13 \\
\hline & 3 & $53: 4: 1$ & 81 & 1,224 & 569 & 310 & 0.14 \\
\hline & 4 & $48: 2: 1$ & 92 & 777 & 366 & 555 & 0.25 \\
\hline & 5 & $71: 4: 1$ & 83 & 897 & 685 & 898 & 0.12 \\
\hline & 6 & $89: 5: 1$ & 113 & 466 & 746 & 435 & 0.15 \\
\hline & 7 & $81: 4: 1$ & 158 & 1,247 & 495 & 1,346 & 0.32 \\
\hline & 8 & $74: 4: 1$ & 213 & 230 & 2,711 & 683 & 0.08 \\
\hline & 9 & $105: 6: 1$ & 83 & 574 & 593 & 707 & 0.14 \\
\hline & 10 & $161: 6: 1$ & 71 & 588 & 805 & 222 & 0.09 \\
\hline \multirow[t]{10}{*}{ Heathlands } & 11 & $305: 13: 1$ & 224 & 1,949 & 318 & 2,682 & 0.71 \\
\hline & 12 & $273: 8: 1$ & 258 & 1,397 & 433 & 3,347 & 0.60 \\
\hline & 13 & $466: 13: 1$ & 373 & 1,369 & 433 & 4,136 & 0.86 \\
\hline & 14 & $428: 12: 1$ & 285 & 622 & 355 & 2,891 & 0.80 \\
\hline & 15 & $614: 14: 1$ & 276 & 2,467 & 525 & 3,423 & 0.52 \\
\hline & 16 & 279:8:1 & 222 & 605 & 489 & 2,776 & 0.45 \\
\hline & 17 & $742: 19: 1$ & 418 & 1,955 & 243 & 5,169 & 1.72 \\
\hline & 18 & $463: 14: 1$ & 243 & 1,201 & 434 & 2,289 & 0.56 \\
\hline & 19 & $764: 20: 1$ & 304 & 3,306 & 431 & 2,419 & 0.70 \\
\hline & 20 & 643:16:1 & 304 & 2,427 & 453 & 2,173 & 0.67 \\
\hline
\end{tabular}

Soil nutritional quality expressed as carbon/nitrogen/phosphorus ratio (in mass units) and as fungal biomass to bacterial biomass ( $F: B$ ratio, on the right)

Fig. 2 Environmental and biotic correlates. Association between the two biotic correlates (fungalto-bacterial biomass ratio, upper row, and number of possible trophic links, lower row) and the two environmental correlates soil acidity (left column) and phosphorus-to-carbon ratio (right column)

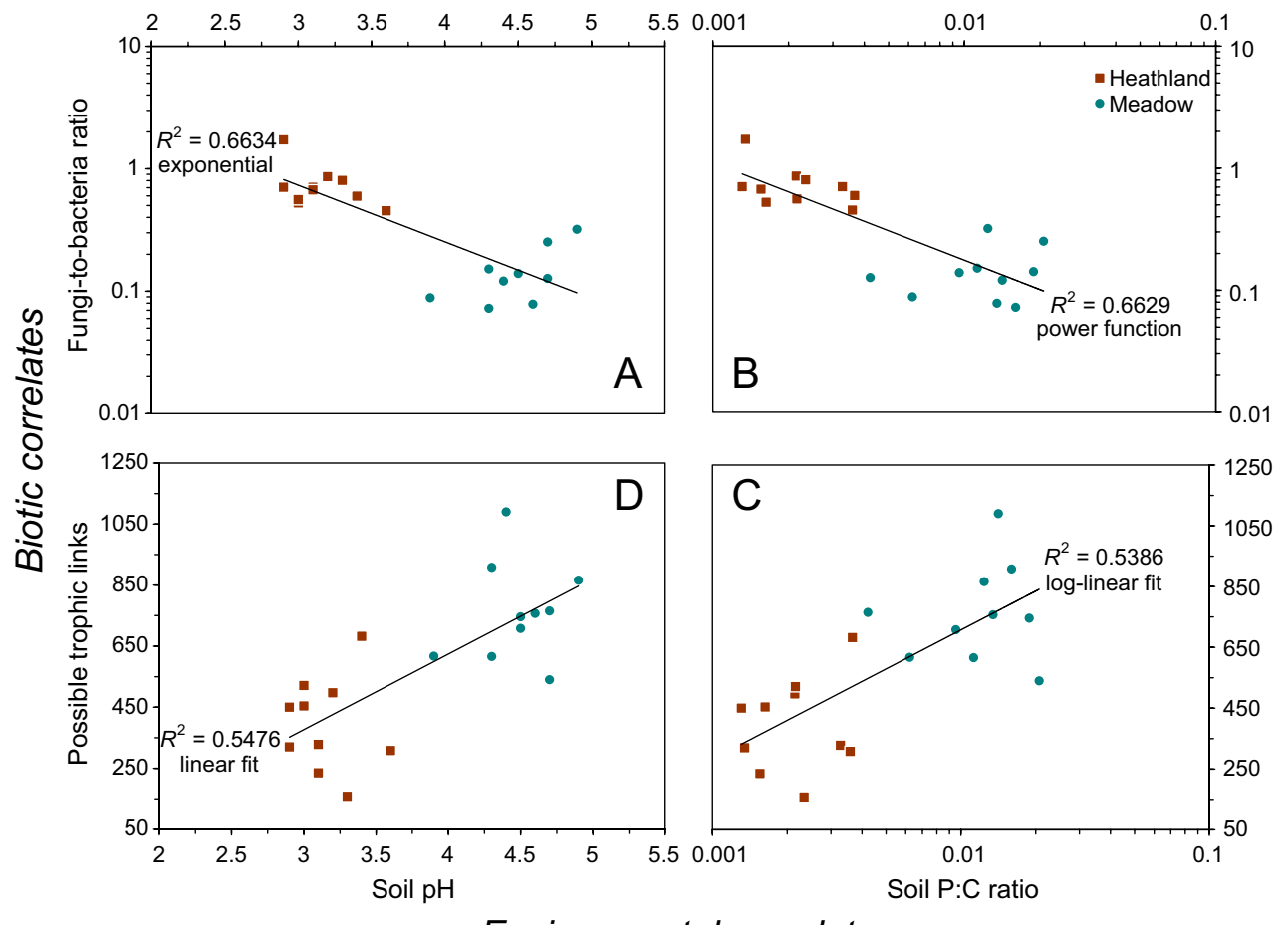

Environmental correlates 

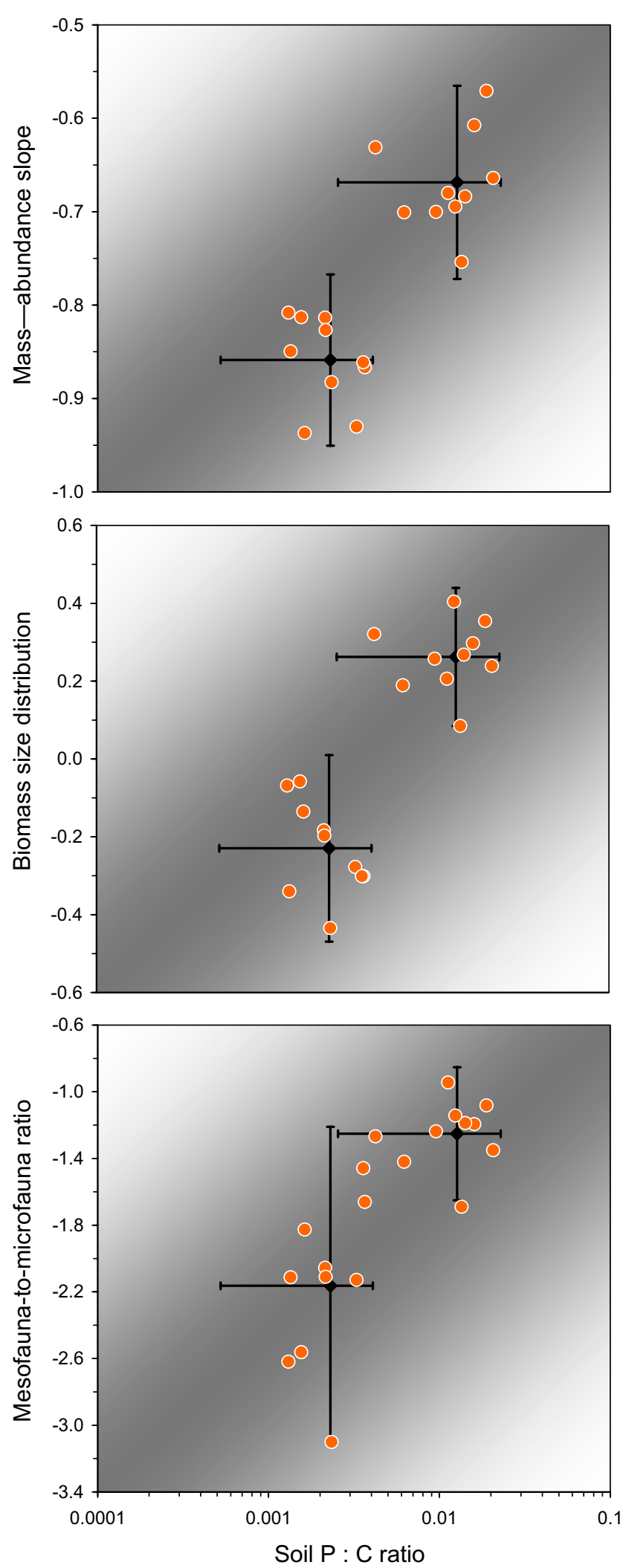

Fig. 3 Size-specific distribution. Common predictor is the ratio between the concentrations of phosphorus and carbon. From top to bottom, log-scaled: mass-abundance slopes, biomass size distribution slopes, and mesofauna-to-microfauna ratio. All allometric indicators were correlated with ecosystem types (heathlands, left, and meadows, right; ANOVA $p<0.0001$; confidence interval set at 95\%), although their variance showed a little overlap. Changes in the nutritional quality of soils are governing the composition of food webs and enable the coupling between aboveground vegetation and belowground soil faunal community

theory (Rossberg et al. 2008). Biomass slopes were always positive in the case of the meadows and negative in the case of the heathlands $(0.262 \pm 0.091 \mathrm{SD}$ and $-0.230 \pm 0.122 \mathrm{SD})$. The average of all investigated mass-abundance relationships was $-0.763 \pm 0.109 \mathrm{SD}$, very close to $-3 / 4$ (e.g., Brown and Gillooly 2003), but the slope distribution has different medians, $-0.669 \pm 0.053 \mathrm{SD}$ for meadows and $-0.859 \pm$ 0.047 SD for heathlands. The Pearson's correlation between each of these three allometric indicators and the soil concentration of phosphorus $(\operatorname{Pr} \leq 0.005)$ forecasts a biochemical interpretation. Specifically, larger invertebrates seem to be favored by increased phosphorus availability (higher nutrient concentrations under mesic conditions, see Table 1). This evidence supports the stoichiometric theory (e.g., Elser 2006), which predicts that organisms with higher phosphorus demands would suffer a competitive disadvantage due to poor stoichiometric food quality. In our case, since low phosphorus concentration hampers microbial degradation in the soil, species with lower phosphorus demands are favored. Such a shift should be recognized in the web structure as well, for instance in the trophic link lengths and in the consumer-resource distributions.

\section{Environment regulates web topology}

If we plot the two components of a consumer-resource ratio against each other, with the population-density ratio of consumer and resource as function of the specific consumerresource body-mass ratio, all communities exhibit conspicuous similarities in the response outcome (Fig. 4). The number of consumers $\left(N_{\mathrm{c}}\right)$ per resource $\left(N_{\mathrm{r}}\right)$ in these community food webs, in fact, seem to assure a proportion of prey kinds to predator kinds that closely reflects their $M_{\mathrm{c}} / M_{\mathrm{r}}$ ratio. Overall, linear regression slopes of $\log \left(N_{\mathrm{c}} / N_{\mathrm{r}}\right)$ as function of $\log \left(M_{\mathrm{c}} / M_{\mathrm{r}}\right)$ fluctuate around $-0.80 \pm 0.05 \mathrm{SD}$, not far from $-3 / 4$ and comparable with studies investigating whether there can be more consumers than resources (Cohen 1978, 2007). We cannot support the assumption that larger consumers handle resources of a given body size faster than smaller consumers (Petchey et al. 2008, Reuman et al. 2009) because the mass-abundance slopes, size spectra, and mesofauna-tomicrofauna ratio (Fig. 3) suggest here the opposite: larger consumers (most fungivores are arthropods) simply handle different resources than smaller consumers (dominant bacter- 


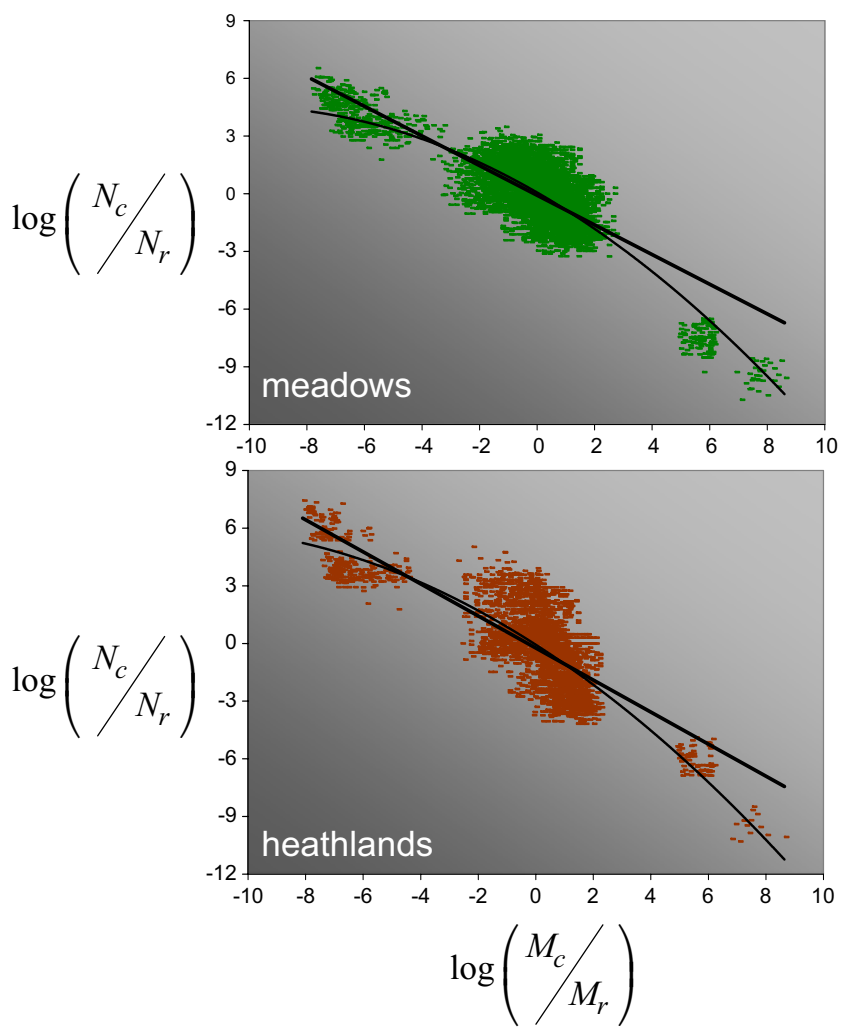

Fig. 4 Consumer-resource pairs. Population-density ratio of consumer and resource (vertical axes) as function of the specific consumerresource body-mass ratio (horizontal axes) in our metacommunities. Above: "meadows", $R^{2}=62.58 \%$, linear slope $-0.771 \pm 0.007 \mathrm{SE}, p<$ 0.0001 , 7,613 pairs; below: "heathlands," $R^{2}=61.34 \%$, linear slope $-0.834 \pm 0.011 \mathrm{SE}, p<0.0001,3,953$ pairs. The parsimonius polynomial equations (all monomials significant) were not better than linear regressions, as squared correlations did not increase in an important way $(3 \%)$

ivore nematodes). Body size clearly matters in territory (larger organisms are more mobile) and in foraging strategy (mobile organisms can become selective).

Being $l=\left|\log \left(M_{\mathrm{c}} / M_{\mathrm{r}}\right)\right|+\left|\log \left(N_{\mathrm{c}} / N_{\mathrm{r}}\right)\right|$ (see "Materials and methods" section), the trophic link length equals the consumer-resource body-mass ratio $\left(M_{\mathrm{c}} / M_{\mathrm{r}}\right)$ only if $\left(N_{\mathrm{c}} / N_{\mathrm{r}}\right)=1$, but in almost all cases, $\log \left(N_{\mathrm{c}} / N_{\mathrm{r}}\right) \neq 0$. Thus, the trophic link length varied as function of the body-mass averages of adult consumers and resource, and as a function of the numerical abundances of consumers and possible resource, making the information that is contained in the metric $l$ (the "trophic link length" on the ordinates of Fig. 5) different from the traditional consumerresource body-mass ratio (the "predator-prey ratio" on the abscissa of Fig. 5). In fact, a length of one trophic link is given in this paper (following Reuman and Cohen 2004) as the number of orders of magnitude difference between the $M$ of the predator and that of the prey, plus the number of

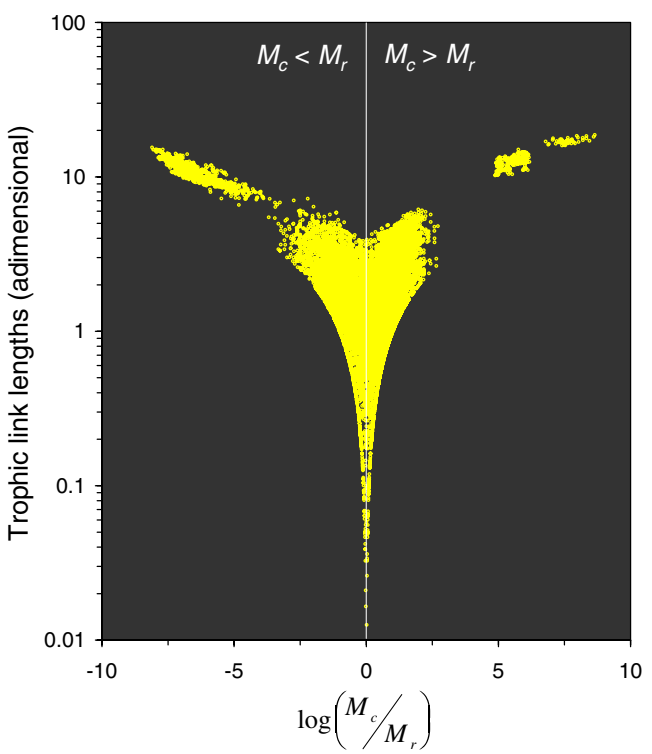

Fig. 5 Consumer-resource body-mass ratios and trophic link lengths. In soil systems the numerical abundance of the population of a consumer can be greater or smaller than the numerical abundance of its resource, making the trophic link length $l$ equal to the consumerresource body-mass ratio only in the case these abundances are equal. The length of the microbial links is by far the longest, where the largest resource (fungal mycelium, negative consumer-resource bodymass ratio) mirrors the smallest resource (bacterial cells, positive consumer-resource body-mass ratio). In aquatic ecosystems, $l$ would be expected to be always longer if the numerical abundance of the resource increases. We used the expectation of whom is capable of eating whom (complete matrix in Suppl. Mat. ESM 1) derived from available literature reporting empirical observations of soil invertebrates during their adult life stage (Mulder et al. 2008)

orders of magnitude difference between the $N$ of the predator and that of the prey (Suppl. Mat. ESM 2). Of all the faunal interactions (Table 2), the slight majority of the trophic links depicts animals preying on invertebrates with a smaller body-mass average, i.e., consumer's $\log \left(M_{\mathrm{c}}\right)$ higher than resource's $\log \left(M_{\mathrm{r}}\right)$. The differences in the

Table 2 Consumer-resource body-mass ratios of soil invertebrates and frequency distribution of faunal trophic links

\begin{tabular}{llll}
\hline & & MEADOWS & HEATHLANDS \\
\hline $\log \left(M_{c} / M_{r}\right)<0$ & length & $1.86 \pm 0.17^{\mathrm{a}}$ & $2.06 \pm 0.30^{\mathrm{a}}$ \\
& links & $274.2 \pm 92.1^{\mathrm{a}}$ & $121.7 \pm 48.9^{\mathrm{b}}$ \\
$\log \left(M_{c} / M_{r}\right)>0$ & length & $1.79 \pm 0.19^{\mathrm{a}}$ & $2.29 \pm 0.19^{\mathrm{b}}$ \\
& links & $424.1 \pm 75.6^{\mathrm{a}}$ & $229.6 \pm 103.4^{\mathrm{b}}$ \\
\hline
\end{tabular}

Means \pm SD and one-way ANOVA results for testing the null hypothesis of no difference between habitats. The average of the trophic link lengths ("length") and the trophic link counts ("links") are provided separately for consumer-resource pairs with consumers smaller than resources and consumers larger than resources. Microbial interactions were not taken into account here; all links consistent with feeding guilds derived from literature survey (Complete matrix in Suppl. Mat. ESM 1). 
possible (faunal) trophic link lengths are less remarkable. The lumped average lengths of all trophic links in our food webs is $2.82 \pm 2.64 \mathrm{SD}$ (Fig. 6). Most trophic links are less than three orders of magnitude long, and their frequency distribution is right-skewed (skewness 1.88, kurtosis 2.16, K-S distance 0.37).

The average number of taxa in our soil community food webs was $49 \pm 9 \mathrm{SD}$. The largest food web (a meadow) contained 62 taxa; the smallest (a heathland) contained 32 taxa. The maximum and minimum number of trophic links per food web is 1,090 and 158 (Suppl. Mat. ESM 2): meadows averaged $761 \pm 161$ SD total connections, heathlands averaged $395 \pm 154$ SD total connections. Structural complexity of the food web ranges from 4.56 to 13.15 links per taxon. Poor systems with low biodiversity (heathlands) display lower links-per-taxon ratios $(7.95 \pm 1.89 \mathrm{SD})$, in contrast to fertile systems with high biodiversity (meadows) that display higher values $(11.16 \pm 1.49 \mathrm{SD})$. The total amount of possible trophic links remains positively correlated with the number of sampled taxa $\left(R^{2}=0.94, F\right.$ ratio $290, p<10^{-11}$ ).

The distributions shown in Fig. 7, where microbial resources are positively correlated with the average of all possible link lengths, suggest that the resulting interactions between fungi and their browsing (large) invertebrates as well as between bacteria and their grazing (small) invertebrates are environmentally dependent. This implies that

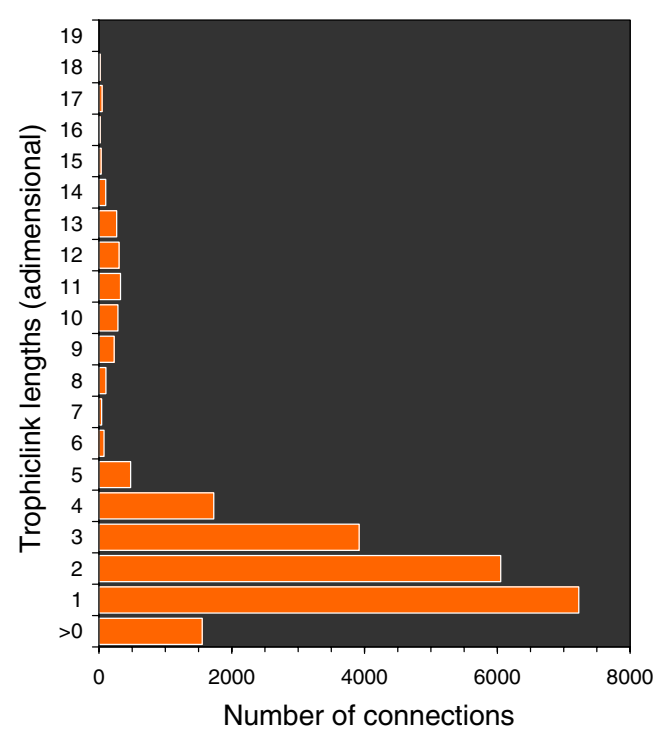

Fig. 6 Paired distribution of the trophic link lengths of soil organisms. The pairs characterized by consumers larger than resources are the majority (pairs average $424 \pm 76 \mathrm{SD}$ in meadows and $230 \pm 103$ $\mathrm{SD}$ in heathlands). In the rare case of cannibalistic loops (occurring 160 times), not only the numerical abundances, but also the bodymass averages are equal ( $l=0$, unplotted). Fungivory and bacterivory are the most specialized feeding strategies: microbivore links are much less than predatory links but have much greater link lengths (Figure 5 and Suppl. Mat. ESM 2) another assumption is more plausible: the smallest living resources (bacteria) will be the most profitable for some consumers, while the largest (mycelium) will be the most profitable for the other consumers. The statement that "diet is a function of consumer body size" (cf. Petchey et al. 2008) holds in our two ecosystems with contrasting microbiology, where the fungal-to-bacterial biomass ratios of heathlands are, on average, fivefold those of meadows. But, in a comparable way to body size, also the number of individuals belonging to a given population matters: thus, functional traits at population level should also include numerical abundance (Díaz et al. 2007).

\section{Discussion}

Current literature holds that both mass-abundance relationships and size-specific biomass distributions are power functions with a negative slope (e.g., Peters 1983; Boudreau et al. 1991; Damuth 2007). This is not always the case in our soil systems: we have indeed always negative mass-abundance slopes and negative biomass slopes in all ten heathlands, but in all ten meadows, we found positive biomass slopes. Although non-negative or nonlinear trends occur on body-mass abscissa spanning up to four orders of magnitude (Boudreau et al. 1991; Ulrich et al. 2005), this is not the case in the current analysis despite our body-mass values cover comparable ranges. Here, mass-abundance and biomass slopes are explained by soil nutrients and, in the case of the sign of biomass slopes, by ecosystem, heathlands being negative. When the soil nutrient ratio decreases by about one order of magnitude (Fig. 3), the slope of $\log (N)$ as a linear function of $\log (M)$ drops from -0.57 to -0.94 . Thus, the lower the soil nutritional quality, the steeper (more negative) the massabundance relationships are. That is, in enriched soils (meadows), the biomass of the larger soil invertebrates is larger relative to the biomass of the smaller animals than in infertile, acidic soils (heathlands). In other words, the lack of nutrients kills off, or diminishes, the relative abundance of large compared to small soil invertebrates. Comparable results have been obtained in aquatic ecosystems, where the organic material supply is known to control the faunal size distribution (Raffaelli et al. 2000).

Despite the huge numerical abundance and species richness of soil organisms, animals with a body size less than $20 \mu \mathrm{m}$ are underrepresented, even in recent metadata (e.g., Brose et al. 2006). Therefore, we agree with the plea by White et al. (2007) for an allometric evaluation of currencies other than numerical abundance for questions related to resource partitioning, and we tried to compare other currencies in the present study. As a matter of fact, abundances of small invertebrates $(M<1 \mu \mathrm{g})$ vary much 
Fig. 7 Community food-web structure. The averages of the trophic link lengths of soil invertebrates closely reflect the specific kind of consumer-resource relation. Length averages were derived from all the links expected from the microbivore community (left figure, see also ESM 2 Online Figures A and B), in meadows (510 expected microbial links) and heathlands ( 378 expected microbial links). The averages of the trophic link lengths for all the soil invertebrates were predictable from the fungal to bacterial biomass ratio (right figure)
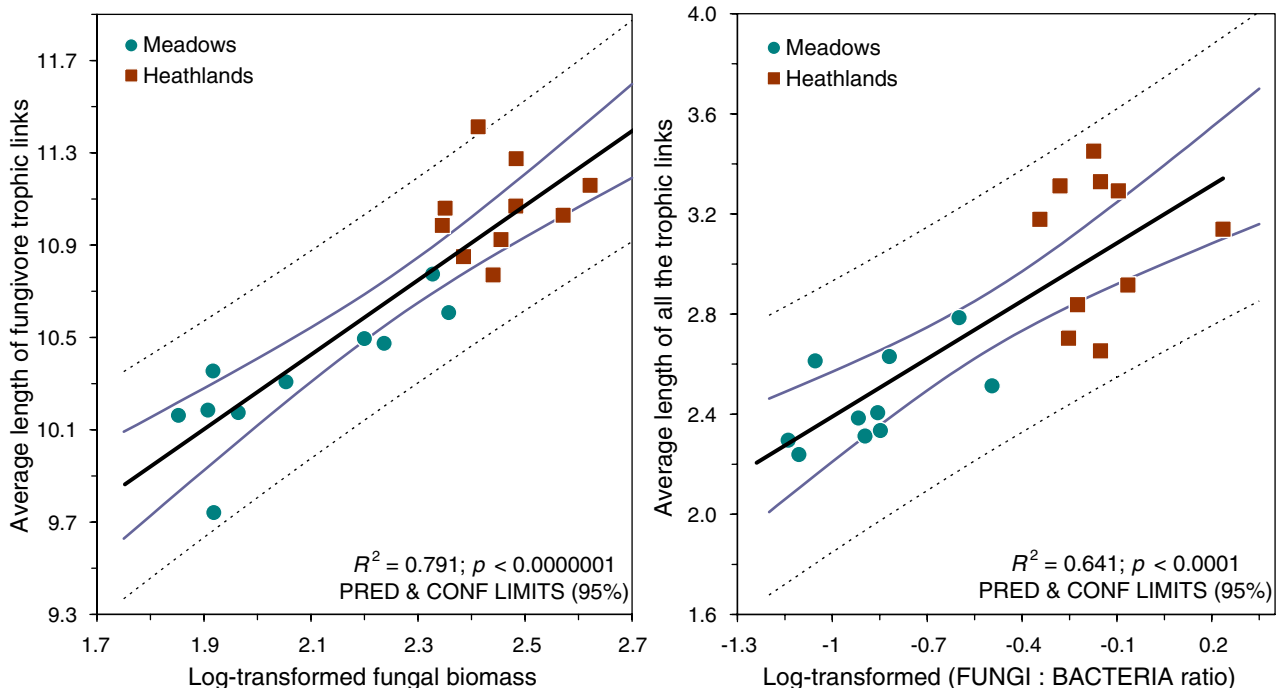

more than those of large invertebrates $(M>1 \mu \mathrm{g})$. The real influence of varying population densities becomes evident by plotting the ratio between mesofauna and microfauna biomass (Fig. 3). The aggregate- $N$ contribution of small invertebrates to the entire faunal community is highest under nutrient deficiency and causes shifts in the massabundance relationships. The variability of the proportion of the population of larger-sized invertebrates in soil systems can be ascribed to the high frequency of generalists and to their indiscriminate feeding on mobile prey (Scheu and Setälä 2002). On the one hand, prey overlap and intraguild predation (Holt and Polis 1997), which result for microarthropods in the domination of omnivory for obtaining supplemental nutrients (cf. Fagan et al. 2002; Denno and Fagan 2003; Cebrian et al. 2009), are related not only to the high numerical abundances of potential resources, but also to the difficulties of locating specific mobile prey (Scheu and Setälä 2002; Mulder 2006). On the other hand, this latter constraint does not hold for microbivory, as the only real specialists in the soil are minute bacterial-grazing nematodes.

A relevant result for microbivory is that the total biomass of soil microbivores is positively correlated with the fungal-tobacterial biomass ratio $(\operatorname{Pr}<0.009)$, but negatively correlated with elemental phosphorus $(\operatorname{Pr}<0.006)$. In the case of fungivores, it probably mirrors a kind of omnivory. Thus, although panherbivore and fungivore microarthropods (mesofauna) seem to consume nutrient-poor food, they tend to consume great quantities of it, in contrast to grazing nematodes (microfauna) that eat frequently food of higher nutritional value, like some arbuscular mycorrhizae, yeasts, and bacteria (Perez-Moreno and Read 2001; Vrede et al. 2002). Incidence of mycorrhizal infections in heathlands, for instance, is much higher than in meadows (Table 1). In passing, we note that a similar occurrence of arbuscular mycorrhizae is claimed to enhance the nutrient uptake of infected plants and contributes to explain increased nutrientuse efficiencies of plants on infertile soils (Chapin et al. 1986; Chapin and Eviner 2003). However, more biomolecular research is necessary to identify trophic implications that can be ascribed entirely to differences in the phosphorus contents of soil, unicellular microbes (including protozoans), and invertebrates. Such data would surely enable major advances in the ecological modeling of real stoichiometric interactions across terrestrial communities.

Brown's theory $(1981,1988)$ indirectly offers an explanation for the strongly positive correlation between the number of trophic links and increasing biodiversity and, in addition to that, also explains why the average lengths of trophic links reflect the "energy diversity," here the fungalto-bacterial biomass ratio. If biodiversity begets instability (May 1974), trophic link lengths might provide the summary of all differentially responding species populations regardless of the number of taxa. From this perspective, nutrient-poor, fungal-rich heathlands, despite their much lower invertebrate diversity, show a higher stability than nutrient-rich and fungal-poor meadows because heathlands behave in a more predictable way. Aboveground biomass production will likely be enhanced by external subsidies in nutrient-limited sites (low phosphorus-tocarbon ratio) and most (phosphorus-rich) autotrophs are known as competitive in nutrient-limited vegetation (cf. Cebrian et al. 2009).

Elser et al. (1998) pointed out that effects of stoichiometrically inadequate food quality may be at the heart of the still ongoing debate about the importance of top-down versus bottom-up driving forces in food webs. Resource supply and resource dynamics are not well represented in existing models because most producer-grazer models have been parameterized to mimic chlorophyll a-Daphnia 
systems due to monetary and logistic constraints on field experimentation with natural populations. Although a solution of this debate is beyond the scope of our paper, we strongly encourage more estimates for the $\mathrm{C} / \mathrm{N} / \mathrm{P}$ utilization in belowground organisms. Most investigation, in fact, continue to address litter arthropods and to focus on the assumption that arthropods tend to select material with higher than average nitrogen content, although the nitrogen availability was not a limiting factor (e.g., Curry 1986; Meehan and Lindroth 2007). Arthropods determine in this way the web topology, as shown by the links of mites feeding on nematodes that share an average length of 3 , comparable to most links of mites feeding on other microarthropods. (Trophic links of soil nematodes feeding on nematodes share an average length of 1.) Thus, taxa belonging to the mesofauna are much more scattered in an allometric plane than taxa belonging to the microfauna. Given that the environment regulates web topology through the larger invertebrates, trophic link lengths depict the independent responses of prey-predator, fungi-consumer, and bacteria-consumer links to the environmental pressures as one community response trait. With the current study, we show that also elemental and microbial energetic resources clearly alter species-level processes in soil systems, in a way consistent with organismal biochemical requirements (Ryther 1969; Sterner and Elser 2002; Elser 2006).

\section{Synthesis and implications}

This study may be the first to examine, model, and interpret structural variation in an ensemble of soil community food webs with body-mass averages, numerical abundances and biomass values, and number and length of possible trophic links between different ecosystems. Community food webs are contingent to spatial definitions and sampling techniques, but functional traits of soil invertebrates like body size might explain the tight connection between abiotic resources, and belowground interactions (e.g., Bengtsson et al. 1996; Bonkowski et al. 2000; Wardle 2002; Wardle et al. 2004; Mulder and Elser 2009). Scheu and Setälä (2002) recognized nematodes as antagonists of bacteria and collembolans as antagonists of fungi: such feedbacks should be ascribed not only to resource availability, but to different food quality. Clearly, the story is not simply about soil nutrients and soil fertility because our results support the resource compartmentation hypothesis (Edwards et al. 1982; Moore and Hunt 1988). Divergent properties of primary decomposers, like small bacterial grazers versus large fungivores, are recognizable across the studied fertility gradient.

Differences in lengths between fungal food-chains and bacterial food-chains might imply a more even distribution of the energy between pathways and a consequent heightening of food-web structure due to the much faster nutrient and energy flow in a bacterial pathway (smallbodied nematodes are much faster to reproduce than arthropods) in comparison to the rather slow flow across a fungal pathway (large-bodied fungivores like collembolans are slower to reproduce than the aforementioned nematodes). These contrasting trends support the classical dichotomy between bacterial- and fungal-dominated energy pathways (Moore and Hunt 1988; Wardle et al. 2004; Mulder 2006). The species' assemblage of the bacterialdominated energy channel seem to recover more rapidly than the species' assemblage of the fungal-dominated energy channel (Hunt et al. 1989) as the functional redundancy of obligate bacterivores like nematodes is much higher than that of facultative fungivores like soildwelling arthropods. Thus, many traits of invertebrates, such as adult body size and life history, clearly matter in soil systems, and confirm the extent to which chemical commonalities as ecological stoichiometry may unify biology, irrespective of taxonomy (Ryther 1969; Elser et al. 2000; Elser and Hamilton 2007; Raffaelli 2007). Still, application of some of these specific predictions associated with nutritional quality, demonstrated without doubt for freshwater and soil food webs, could be much more contentious for aboveground food webs.

Summarizing, the lengths of the trophic links within a soil community reflect resource availability, both elemental resources and microbial resources, and depict independent energy pathways in soil systems. We believe that this new evidence is consistent with the view that allometry allows for the recognition of the extent to which soil nutrients and microbes weave community food webs. We find that allometric indicators are superior to previous indicators of governing processes as they provide a common currency to predict real resource availability. Nutritional quality acts as general stoichiometric constraint on the variation in the structure of soil food webs in a comparable way to that of aquatic food webs. In freshwater environments, in fact, phosphorus is typically the limiting nutrient, and biotic demand matches its availability (Beisner et al. 2003; but see Rabalais 2002).

The real limiting influence of phosphorus must be analyzed in living soil organisms. For instance, how does the trend hold for entirely different biota? (Compare Elser et al. 2003 with Read 1991.) To identify possible outliers of a correlation between soil nutritional quality and trophic structure, soil food webs from arid dunefields extremely deficient in phosphorus, widely regarded as infertile in central Australia and southern Africa (Palm et al. 2007), and Pacific islands enriched by seabirds depositing P-rich guano (Fukami et al. 2006) should be investigated in the future to extend the observed variation in the trophic structure to different biota and other biomes. 
Acknowledgments The authors thank T. Aldenberg and A.M. Breure for thorough comments, H.J. van Wijnen, W. Dimmers and J. Bloem for technical analysis, and the anonymous referees for precious suggestions. A.G.R. gratefully acknowledges support by a Beaufort Marine Research Award by the Marine Institute, under the Sea Change Strategy and the Strategy for Science, Technology and Innovation, funded under the Irish National Development Plan (2007-2013). C.M. and H.A.D.H. were supported by the RIVM Directorate (QERAS S/860703 and EIA S/607001) and by the Scientific Advisory Committee of the Netherlands Ministry of Housing, Spatial Planning, and Environment (VROM). Investigation was performed upon the demand of the Directorate "Soil, Water and Rural Area" of the Netherlands VROM Ministry (C.M.).

Open Access This article is distributed under the terms of the Creative Commons Attribution Noncommercial License which permits any noncommercial use, distribution, and reproduction in any medium, provided the original author(s) and source are credited.

\section{References}

Bakken LR, Olsen RA (1983) Buoyant densities and dry-matter contents of microorganisms: conversion of a measured biovolume into biomass bacteria and fungi from soil. Appl Environ Microbiol 45:1188-1195

Beisner BE, Dent CL, Carpenter SR (2003) Variability of lakes on the landscape: roles of phosphorus, food webs, and dissolved organic carbon. Ecology 84:1563-1575. doi:10.1890/0012-9658(2003) 084[1563:VOLOTL]2.0.CO;2

Bengtsson J, Setälä H, Zheng DW (1996) Food-webs and nutrient cycling in soils: interactions and positive feedbacks. In: Polis GA, Winemiller KO (eds) Food-webs: integration of patterns and dynamics. Chapman \& Hall, New York, pp 30-38

Berlow EL, Brose U, Martinez ND (2008) The "Goldilocks factor" in food webs. Proc Natl Acad Sci USA 105:4079-4080. doi:10.1073/pnas.0800967105

Bonkowski M, Cheng W, Griffiths B, Alphei J, Scheu S (2000) Microbial faunal interactions in the rhizosphere and effects on plant growth. Eur J Soil Biol 36:135-147. doi:10.1016/S1164-5563(00)01059-1

Boudreau PR, Dickie LM, Kerr SR (1991) Body-size spectra of production and biomass as system-level indicators of ecological dynamics. J Theor Biol 152:329-339. doi:10.1016/S0022-5193 (05)80198-5

Brose U, Jonsson T, Berlow EL, Warren P, Banašek-Richter C, Bersier LF, Blanchard JL, Brey T, Carpenter SR, Cattin Blandenier MF, Cushing L, Dawah HA, Dell T, Edwards F, Harper-Smith S, Jacob U, Ledger ME, Martinez ND, Memmott J, Mintenbeck K, Pinnegar JK, Rall BC, Rayner TS, Reuman DC, Ruess L, Ulrich W, Williams RJ, Woodward G, Cohen JE (2006) Consumer-resource body-size relationships in natural food webs. Ecology 87:2411-2417. doi:10.1890/0012-9658(2006)87[2411:CBRINF]2.0.CO;2

Brown JH (1981) Two decades of a homage to Santa Rosalia: toward a general theory of diversity. Am Zool 21:877-888

Brown JH (1988) Species diversity. In: Myers AA, Giller PS (eds) Analytical biogeography - an integrated approach of the study of animal and plant distribution. Chapman \& Hall, London, pp 57-89

Brown JH, Gillooly JF (2003) Ecological food webs: high-quality data facilitate theoretical unification. Proc Natl Acad Sci USA 103:1467-1468. doi:10.1073/pnas.0630310100

Cebrian J, Shurin JB, Borer ET, Cardinale BJ, Ngai JT, Smith MD, Fagan WF (2009) Producer nutritional quality controls ecosystem trophic structure. PLoS ONE 4:e4929. http://www.plosone.org/ article/info\%3Adoi\%2F10.1371\%2Fjournal.pone.0004929
Chapin FS III, Eviner VT (2003) Biogeochemistry of terrestrial net primary production. Treatise Geochem 8:215-247

Chapin FS III, Vitousek PM, Van Cleve K (1986) The nature of nutrient limitation in plant communities. Am Nat 127:48-58. doi: $10.1086 / 284466$

Cohen JE (1978) Food webs and niche space. Monogr Popul Biol 11:1-189

Cohen JE (2007) Body sizes in food chains of animal predators and parasites. In: Hildrew AG, Raffaelli DG, Edmonds-Brown R (eds) Body size: the structure and function of aquatic ecosystems. Cambridge University Press, New York, pp 306-325

Curry JP (1986) Above-ground arthropod fauna of four Swedish cropping systems and its role in carbon and nitrogen cycling. $\mathrm{J}$ Appl Ecol 23:853-870. doi:10.2307/2403939

Damuth J (2007) A macroevolutionary explanation for energy equivalence in the scaling of body size and population density. Am Nat 169:621-631. doi:10.1086/513495

Denno RF, Fagan WF (2003) Might nitrogen limitation promote omnivory among carnivorous arthropods? Ecology 84:25222531. doi:10.1890/02-0370

Díaz S, Lavorel S, De Bello F, Quétier F, Grigulis K, Robson TM (2007) Incorporating plant functional diversity effects in ecosystem service assessments. Proc Natl Acad Sci USA 104:20684-20689. doi:10.1073/pnas.0704716104

Edwards DC, Conover DO, Sutter F III (1982) Mobile predators and the structure of marine intertidal communities. Ecology 63:11751180. doi:10.2307/1937256

Elser J (2006) Biological stoichiometry: a chemical bridge between ecosystem ecology and evolutionary biology. Am Nat 168:S25S35. doi:10.1086/509048

Elser JJ, Hamilton A (2007) Stoichiometry and the new biology: the future is now. PLoS Biol 5:e181. http://biology.plosjournals.org/ perlserv $/$ ? request $=$ get-document $\&$ do $i=10.1371 /$ journal . pbio.0050181

Elser JJ, Chrzanowski TH, Sterner RW, Mills KH (1998) Stoichiometric constraints on food-web dynamics: a whole-lake experiment on the Canadian Shield. Ecosystems 1:120-136. doi:10.1007/s100 219900009

Elser JJ, Sterner RW, Galford AE, Chrzanowski TH, Findlay DL, Mills KH, Paterson MJ, Stainton MP, Schindler DW (2000) Pelagic C:N:P stoichiometry in a eutrophied lake: responses to a whole-lake food-web manipulation. Ecosystems 3:293-307. doi:10.1007/s100210000027

Elser JJ, Acharya K, Kyle M, Cotner J, Makino W, Markow T, Watts T, Hobbie S, Fagan W, Schade J, Hood J, Sterner RW (2003) Growth rate-stoichiometry couplings in diverse biota. Ecol Lett 6:936-943. doi:10.1046/j.1461-0248.2003.00518.x

Fagan WF, Siemann E, Mitter C, Denno RF, Huberty AF, Woods HA, Elser JJ (2002) Nitrogen in insects: implications for trophic complexity and species diversification. Am Nat 160:784-802. doi:10.1086/343879

Fukami T, Wardle DA, Bellingham PJ, Mulder CPH, Towns DR, Yeates GW, Bonner KI, Durrett MS, Grant-Hoffman MN, Williamson WM (2006) Above- and below-ground impacts of introduced predators in seabird-dominated island ecosystems. Ecol Lett 9:1308-1320. doi:10.1111/j.1461-0248.2006.00983.x

Hendriks AJ, Mulder C (2008) Scaling of offspring number and mass to plant and animal size: model and meta-analysis. Oecologia 155:705-716. doi:10.1007/s00442-007-0952-3

Herbert D (1976) Stoichiometric aspects of microbial growth. In: Dean ACR, Ellwood DC, Evans CGT, Melling J (eds) Continuous Culture 6: application and new fields. Ellis Horwood, Chichester, UK, pp 1-30

Holt RD, Polis GA (1997) A theoretical framework for intraguild predation. Am Nat 149:745-764. doi:10.1086/286018

Holterman M, Van der Wurff A, Van den Elsen S, Van Megen H, Bongers T, Holovachov O, Bakker J, Helder J (2006) Phylum-wide analysis 
of SSU rDNA reveals deep phylogenetic relationships among nematodes and accelerated evolution toward crown clades. Mol Biol Evol 23:1792-1800. doi:10.1093/molbev/msl044

Holterman M, Rybarczyk K, Van den Elsen S, Van Megen H, Mooyman P, Peña Santiago R, Bongers T, Bakker J, Helder J (2008) A ribosomal DNA-based framework for the detection and quantification of stress-sensitive nematode families in terrestrial habitats. Mol Ecol Res 8:23-34. doi:10.1111/j.1471-8286. 2007.01963.x

Hunt HW, Coleman DC, Ingham ER, Ingham RE, Elliot ET, Moore JC, Rose SL, Reid CPP, Morley CR (1987) The detrital food web in a shortgrass prairie. Biol Fertil Soils 3:57-68. doi:10.1007/ BF00260580

Hunt HW, Elliott ET, Walter DE (1989) Inferring trophic transfers from pulse-dynamics in detrital food webs. Plant Soil 115:247259. doi: $10.1007 / \mathrm{BF} 02202593$

Kondoh M (2005) Is biodiversity maintained by food-web complexity? - the adaptive food-web hypothesis. In: Belgrano A, Scharlier UM, Dunne J, Ulanowicz RE (eds) Aquatic food webs - an ecosystem approach. Oxford University Press, Oxford, pp 130-142

Loladze I, Kuang Y, Elser JJ, Fagan WF (2004) Competition and stoichiometry: coexistence of two predators on one prey. Theor Popul Biol 65:1-15. doi:10.1016/S0040-5809(03)00105-9

May RM (1974) Stability and complexity in model ecosystems (2nd ed.). Monogr Popul Biol 6:1-265

Meehan TD, Lindroth RL (2007) Modeling nitrogen flux by larval insect herbivores from a temperate hardwood forest. Oecologia 153:833-843. doi:10.1007/s00442-007-0797-9

Mikola J, Setälä H (1999) Interplay of omnivory, energy channels and $\mathrm{C}$ availability in a microbial-based soil food web. Biol Fertil Soils 28:212-218. doi:10.1007/s003740050485

Moore JC, Hunt HW (1988) Resource compartmentation and the stability of real ecosystems. Nature 333:261-263. doi:10.1038/333261a0

Moore JC, Walter DE, Hunt HW (1988) Arthropod regulation of micro- and mesobiota in below-ground detrital food web. Annu Rev Entomol 33:419-439. http://arjournals.annualreviews.org/ doi/abs/10.1146/annurev.en.33.010188.002223

Mulder C (2006) Driving forces from soil invertebrates to ecosystem functioning: the allometric perspective. Naturwissenschaften 93:467-479. doi:10.1007/s00114-006-0130-1

Mulder C, Elser JJ (2009) Soil acidity, ecological stoichiometry and allometric scaling in grassland food webs. Glob Change Biol 15. doi:10.1111/j.1365-2486.2009.01899.x

Mulder C, Janssen CR (1999) Occurrence of pollen and spores in relation to present-day vegetation in a Dutch heathland area. J Veg Sci 10:87-100. doi:10.2307/3237164

Mulder C, De Zwart D, Van Wijnen HJ, Schouten AJ, Breure AM (2003) Observational and simulated evidence of ecological shifts within the soil nematode community of agroecosystems under conventional and organic farming. Funct Ecol 17:516-525. doi:10.1046/j.1365-2435.2003.00755.x

Mulder C, Cohen JE, Setälä H, Bloem J, Breure AM (2005a) Bacterial traits, organism mass, and numerical abundance in the detrital soil food web of Dutch agricultural grasslands. Ecol Lett 8:8090. doi:10.1111/j.1461-0248.2004.00704.x

Mulder C, Van Wijnen HJ, Van Wezel AP (2005b) Numerical abundance and biodiversity of below-ground taxocenes along a $\mathrm{pH}$ gradient across the Netherlands. J Biogeogr 32:1775-1790. doi:10.1111/j.1365-2699.2005.01321.x

Mulder C, Den Hollander H, Schouten T, Rutgers M (2006) Allometry, biocomplexity, and web topology of hundred agroenvironments in the Netherlands. Ecol Complex 3:219-230. doi:10.1016/j.ecocom.2006.05.004

Mulder C, Den Hollander HA, Hendriks AJ (2008) Aboveground herbivory shapes the biomass distribution and flux of soil invertebrates. PLoS ONE 3:e3573. http://www.plosone.org/article/info\%3Adoi\%2F10.1371\%2Fjournal.pone.0003573

Murphy LJ, Riley JP (1962) A modified single solution method for determination of phosphate in natural waters. Anal Chim Acta 27:31-36

Palm C, Sanchez P, Ahamed S, Awiti A (2007) Soils: a contemporary perspective. Annu Rev Environ Resour 32:99-129. doi:10.1146/ annurev.energy.31.020105.100307

Perez-Moreno J, Read DJ (2001) Nutrient transfer from soil nematodes to plants: a direct pathway provided by the mycorrhizal mycelial network. Plant Cell Environ 24:1219-1226. doi:10.1046/j.1365-3040.2001.00769.x

Petchey OL, Beckerman AP, Riede JO, Warren PH (2008) Size, foraging, and food web structure. Proc Natl Acad Sci USA 105:4191-4196. doi:10.1073/pnas.0710672105

Peters RH (1983) The ecological implications of body size. Cambridge University Press, Cambridge, UK

Pimm SL, Kitching RL (1987) The determinants of food chain lengths. Oikos 50:302-307. doi:10.2307/3565490

Pimm SL, Lawton JH (1978) On feeding on more than one trophic level. Nature 275:542-544. doi:10.1038/275542a0

Pimm SL, Rice JC (1987) The dynamics of multispecies, multi-life-stage models of aquatic food webs. Theor Popul Biol 32:303-325. doi:10.1016/0040-5809(87)90052-9

Ponge J-F (2000) Vertical distribution of Collembola (Hexapoda) and their food resources in organic horizons of beech forests. Biol Fertil Soils 32:508-522. doi:10.1007/s003740000285

Powell JR (2007) Linking soil organisms within food webs to ecosystem functioning and environmental change. Adv Agron 96:307-350. doi:10.1016/S0065-2113(07)96007-1

Rabalais NN (2002) Nitrogen in aquatic ecosystems. Ambio 31:102112

Raffaelli D (2007) Food webs, body size and the curse of the Latin binomial. In: Rooney N, McCann KS, Noakes DLG (eds) From energetics to ecosystems: the dynamics and structure of ecological systems. Springer, Dordrecht, pp 53-64

Raffaelli D, Hall S, Emes C, Manly B (2000) Constraints on body size distributions: an experimental approach using a small-scale system. Oecologia 122:389-398. doi:10.1007/ s004420050045

Read RJ (1991) Mycorrhizas in ecosystems. Experientia 47:376-391. doi:10.1007/BF01972080

Reuman DC, Cohen JE (2004) Trophic links' length and slope in the Tuesday Lake food web with species' body mass and numerical abundance. J Anim Ecol 73:852-866. doi:10.1111/j.00218790.2004.00856.x

Reuman DC, Mulder C, Raffaelli D, Cohen JE (2008) Three allometric relations of population density to body mass: theoretical integration and empirical tests in 149 food webs. Ecol Lett 11:1216-1228. http://www3.interscience.wiley.com/ journal/121412133/abstract

Reuman DC, Cohen JE, Mulder C (2009) Human and environmental factors influence soil faunal abundance-mass allometry and structure. Adv Ecol Res 41:45-85. doi:10.1016/S0065-2504(09) 00402-4

Rossberg AG, Ishii R, Amemiya T, Itoh K (2008) The top-down mechanism for body-mass-abundance scaling. Ecology 89:567580. doi:10.1890/07-0124.1

Ryther JH (1969) Photosynthesis and fish production in the sea. Science 166:72-76. doi:10.1126/science.166.3901.72

Scheu S, Setälä H (2002) Multitrophic interactions in decomposer food-webs. In: Tscharntke T, Hawkins BA (eds) Multitrophic level interactions. Cambridge University Press, Cambridge, UK, pp 223-264

Setälä H, Tyynismaa M, Martikainen E, Huhta V (1991) Mineralization of $\mathrm{C}, \mathrm{N}$ and $\mathrm{P}$ in relation to decomposer community 
structure in coniferous forest soil. Pedobiologia (Jena) $35: 285-296$

Setälä H, Marshall VG, Trofymow JA (1996) Influence of body size of soil fauna on litter decomposition and ${ }^{15} \mathrm{~N}$ uptake by poplar in a pot trial. Soil Biol Biochem 28:1661-1675. doi:10.1016/ S0038-0717(96)00252-0

Siepel H (1994) Life-history tactics of soil microarthropods. Biol Fertil Soils 18:263-278. doi:10.1007/BF00570628

Sterner RW, Elser JJ (2002) Ecological stoichiometry: the biology of elements from molecules to the biosphere. Princeton University Press, Princeton, NJ

Ulrich W, Buszko J, Czarnecki A (2005) The local interspecific abundance-body weight relationship of ground beetles: a counterexample to the common pattern. Pol J Ecol 53:585589

Van Veen JA, Paul EA (1979) Conversion of biovolume measurements of soil organisms, grown under various moisture tensions, to biomass and their nutrient content. Appl Environ Microbiol $37: 686-692$

Vrede K, Heldal M, Norland S, Bratbak G (2002) Elemental composition $(\mathrm{C}, \mathrm{N}, \mathrm{P})$ and cell volume of exponentially growing and nutrient-limited bacterioplankton. Appl Environ Microbiol 68:2965-2971. doi:10.1128/AEM.68.6.2965-2971.2002

Wardle DA (2002) Communities and ecosystems: linking the aboveground and belowground components. Monogr Popul Biol 34:1-408

Wardle DA, Bardgett RD, Klironomos JN, Setälä H, Van der Putten W, Wall DH (2004) Ecological linkages between aboveground and belowground biota. Science 304:1629-1633. doi:10.1126/ science. 1094875

White EP, Ernest SKM, Kerkhoff AJ, Enquist BJ (2007) Relationships between body size and abundance in ecology. Trends Ecol Evol 22:323-330. doi:10.1016/j.tree.2007.03.007

Woodward G, Ebenman B, Emmerson M, Montoya JM, Olesen JM, Valido A, Warren PH (2005) Body size in ecological networks. Trends Ecol Evol 20:402-409. doi:10.1016/j.tree.2005.04.005

Yeates GW (1987a) Nematode feeding and activity: the importance of development stages. Biol Fertil Soils 3:143-146. doi:10.1007/ BF00260596

Yeates GW (1987b) Significance of developmental stages in the coexistence of three species of Mononchoidea (Nematoda) in a pasture soil. Biol Fertil Soils 5:225-229. doi:10.1007/BF00256905

Yeates GW (1987c) How plants affect nematodes. Adv Ecol Res 17:61-113. doi:10.1016/S0065-2504(08)60244-5

Yeates GW (1999) Effects of plants on nematode community structure. Annu Rev Phytopathol 37:127-149. doi:10.1146/annurev. phyto.37.1.127

Yeates GW (2003) Nematodes as soil indicators: functional and biodiversity aspects. Biol Fertil Soils 37:199-210. doi:10.1007/ s00374-003-0586-5

Yeates GW, Bongers T (1999) Nematode diversity in agroecosystems. Agric Ecosyst Environ 74:113-135. doi:10.1016/S0167-8809(99) 00033-X

Yeates GW, Bongers T, De Goede RGM, Freckmann DW, Georgieva SS (1993) Feeding habits in nematode families and genera - an outline for soil ecologists. J Nematol 25:315-331 